\title{
THE EFFECT OF SOCIAL MEDIA INFLUENCER ON BRAND IMAGE, SELF-CONCEPT, AND PURCHASE INTENTION
}

\author{
Atika Hermanda*), Ujang Sumarwan ${ }^{2}$, dan Netti Tinaprilla ${ }^{3}$ \\ ${ }^{1}$ Management and Business, Business School, IPB University, Indonesia, 16151 \\ ${ }^{2}$ Department of Family and Consumer Sciences, Faculty of Human Ecology, IPB \\ University, Indonesia, 16680 \\ ${ }^{3}$ Department of Agribusiness, Faculty of Economics and Management, IPB University, \\ Indonesia, 16680 \\ *Corresponding author: atikahermanda@gmail.com
}

\begin{abstract}
The purpose of the research was to discover how social media influencers influenced the brand image, self-concept and the purchase intention of cosmetic consumers. The social media influencers became the third party which provided information about cosmetic products to the social media audience. Those who had the same self-concept with the influencers often viewed them as role models in consumption. The increase of self-concept and brand image affected a consumer's purchase intention. The research would implement the cross sectional design, with the data gathered through online questionnaires shared in social media accounts. The samples would be gathered using the convenience sampling technique, with respondents up to 219 people. The research implemented the purchase intention as the endogenous variable and social media influencers as the exogenous variable, as well as brand image and self-concept as the intervening variable. The analysis method that would be implemented was the Structural Equation Modeling (SEM), using the SmartPLS software. The research resulted in the significant negative influence of both social media influencer and self concept towards the purchase intention, in contrast with the brand image which had a significant positive effect.
\end{abstract}

Keywords: brand image, social media, social media influencer, self-concept, purchase intention

\begin{abstract}
Abstrak
Penelitian ini bertujuan untuk mengetahui pengaruh social media influencer terhadap brand image, konsep diri dan minat beli konsumen kosmetik. Influencer dari media sosial adalah pihak ketiga yang memberikan informasi produk kosmetik kepada audiensi di media sosial. Rekomendasi produk dari social media influencer dapat memengaruhi opini konsumen. Konsumen yang merasakan konsep diri yang sama dengan social media influencer akan cenderung menjadikannya sebagai panutan dalam mengkonsumsi. Peningkatan konsep diri konsumen dan citra merek di benak konsumen diduga dapat mempengaruhi minat beli konsumen. Desain penelitian ini adalah cross sectional. Data diperoleh dari kuesioner online yang disebarluaskan melalui media sosial. Adapun teknik pemilihan sampel yang digunakan penelitian ini adalah
\end{abstract}


convenience sampling. Responden yang didapatkan yaitu sebanyak 219 responden. Variabel endogen yang digunakan dalam penelitian ini adalah minat beli sementara variabel eksogen yaitu social media influencer. Variabel intervening yang digunakan adalah citra merek dan konsep diri. Metode analisis dalam penelitian ini yaitu Structural Equation Modeling (SEM) menggunakan perangkat lunak SmartPLS. Hasil yang diperoleh adalah social media influencer dan konsep diri tidak berpengaruh positif signifikan terhadap minat beli. Sementara itu, brand image memiliki pengaruh positif signifikan terhadap minat beli.

Kata kunci: media sosial, social media influencer, brand image, konsep diri, minat beli

\section{Introduction}

Currently, the social media was an online communication tool that made a huge impact towards the society (Dân \& Nam 2018), encouraging companies to expand their marketing practices in the social media. In the previous research, tradisional marketing media such as televisions, magazines, and radios were currently unstable and ineffective due to the change of market brought by the internet (Opreana \& Vinerean, 2015; Tiago \& Verissimo, 2014). Moreover, product recommendations from social media influencers received a higher trust rate compared to products recommended by families or friends, resulting in $40 \%$ of consumers purchased the products used by social media influencers (Sekhon et al., 2016).

Social media influencers were individuals who actively used their social media accounts and often involved in a certain topic, as well as providing new information (Loeper et al., 2014). Social media influencers often used products according to their lifestyle and shared the reviews in their social media accounts. As stated by Munukka et al. (2016), an influencer could evaluate a product that consumers would admire, encouraging them to purchase it. Furthermore, they provided the latest information and were able to influence consumers' attitudes and behaviors (Liu et al., 2015). There were several experts who believed that social media influencers would increase over the years, since the use of social media influencers as a marketing media was becoming popular in Indonesia. Until 2018, companies in Indonesia had allocated their marketing budget for social media influencers around $20-30 \%$ higher than last year.

Social media influencers could also act as the third party that recommended and described the products through the social media contents, which could influence the consumers' opinions, behaviors, and attitudes towards a product (Uzunoglu \& Klip, 2014). Consumers who searched for information about the product often tought the social media influencers as a trustworthy source of information (Wang et al., 2012; Park \& Cho, 2012).

Consumers also often received more messages about the product from social media influencers than from companies (De Veirman et al., 2017). Solomon (2017) stated that social media influencers influenced the perceptions of consumers towards the product. It was also in accordance with a research by Ateke (2013), stating that the higher the perception, the higher the product's brand images used by influencers as well. Furthermore, Godey et al. (2016) stated that the marketing practice through social media influencers would result in a positive connection with the brand image, as the 
information shared through the social media were more effective in affecting the behaviors and purchase intention of consumers (Labrecque et al., 2013).

The result of the research stated that social media users indirectly viewed social media influencers as role models in terms of lifestyle, as consumers could view similarities between them and the influencers through the social media (Choi \& Rifon, 2012). They also viewed the influencers as the desired ideal concept. According to McCracken (1989), a consumer obtained a self-concept of satisfaction when using the same product as their idols, while the self-concept of perception was reflected throught the consumer's behavior (Sumarwan, 2015). The similarities of self-concepts between consumers and social media influencers could create the purchase intention (Choi \& Rifon, 2012; Ilicic \& Webster, 2015).

Through the explanations about the result of the resaerch and theories about the social media marketing, brand image, self-concept, and purchase intention, there were no current researches that combined such variables to study the local cosmetic products. The majority of local cosmetic companies in Indonesia were still dependent with the traditional marketing strategy, such as televisions, newspapers, or radios, which was outdated by the growing promotions of imported beauty products through online media, that gathered a wider range of consumers. Imported beauty products also began to enter in large shopping centers that can enhance the company's image. According to Yunita \& Rosa (2016), there are several factors that make consumers tend to choose imported beauty products, one of which is consumers feel unfamiliar to local beauty products because the advertisements and promotions do not reach consumers. It was believed that the promotion strategy through social media influencers could increase the sales of local cosmetic products in Indonesia, as well as broadening the reach of the promotion in order to compete with imported cosmetic products. Based on the research background, the purpose of the research was to furtherly understand the concept of social media influencers towards the brand image, self-concept and purchase intention of local cosmetic consumers and formulate the implemented managerial implications. The conceptual framework of the research, along with the hypotheses, could be seen in Image 1.

$\mathrm{H}_{1}$ : Social media influencer has a significant positive effect on purchase intention

$\mathrm{H}_{2}$ : Social media influencer has a significant positive effect on brand image

$\mathrm{H}_{3}$ : Social media influencer has a significant positive effect on self-concept

$\mathrm{H}_{4}$ : Brand image has a significant positive effect on purchase intention

$\mathrm{H}_{5}$ : Self-concept has a significant positive effect on purchase intention

H1

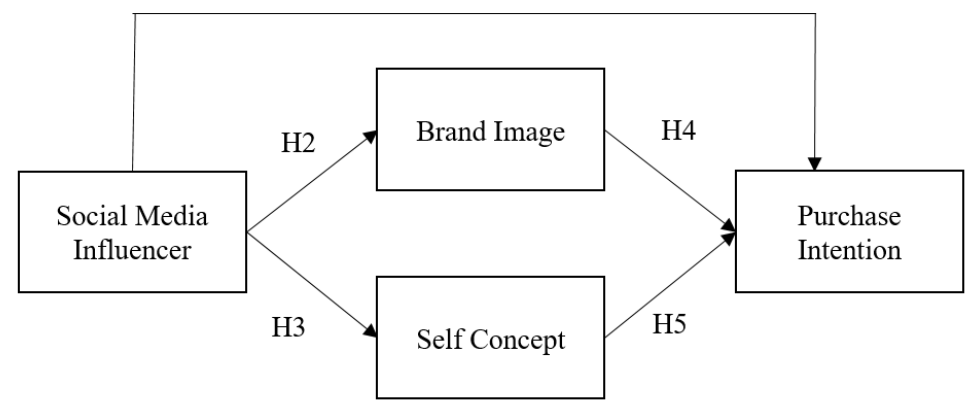

Figure 1 Conceptual Framework 


\section{Methods}

The reasearch period was around a three-month period or during October until December of 2018, using the quantitative approach. The research implemented the cross sectional design, in order to discover the connection between the independent and dependent variables. The primary data was obtained through online questionnaires in the Google Docs link, shared in the social media applications such as WhatsApp, Instagram, and Twitter. The questionnaires consisted of (closed) structural questions, with the non-probability sampling technique.

Randomization is not important in nonprobability sampling when selecting samples from the interest population. Subjective methods are instead used to determine which elements are included in the sample. Therefore, non-probability sampling is a sampling technique in which samples are collected in a process that does not give all participants or units in the population equal opportunities to be collected. Determining the nonprobability sampling technique that applicable to the study is very important for a researcher. In this study, convenience sampling was chosen because the subject was very close to the researcher where it was easier for researchers to access.

Convenience sampling is known as haphazard sampling or accidental sampling which is a type of nonprobability or nonrandom sampling in which members of the target population meet certain practical criteria, such as easy accessibility, geographical proximity, availability at a certain time or desire to participate in the reseach. Convenience sampling is a technique that makes it easy for researchers because it's pretty affordable, easy and the subjects are available. Researcher must essentially explain how the sample will differ from the one selected randomly. It is also important $t$ describe the topic that could be excluded during the selection process or the topic represented in the sample.

The criteria of respondents were at the age range of older than 17 years old and had purchased products recommended by social media influencers for the last six months. The chosen age range was in the assumption that consumers had a tendency to make product purchase intentions during such age. The respondents of the research were 219 respondents, based on the fact that the indicator was implemented around 5-10 times more than the assumed amount of the parameter.

The research implemented the dependent variable or the endogenous variable (Y), which was the purchase intention, the independent variable or the exogenous variable (X) (social media influencers); and the intervening variables which were the brand image (Z1) and the self-concept (Z2). The operational definitions of the research could be seen in Table 1. The data process in this research implemented the use of softtwares such as Microsoft Excel 2007, SPSS and SmartPLS.

Table 1 Variables and Indicators

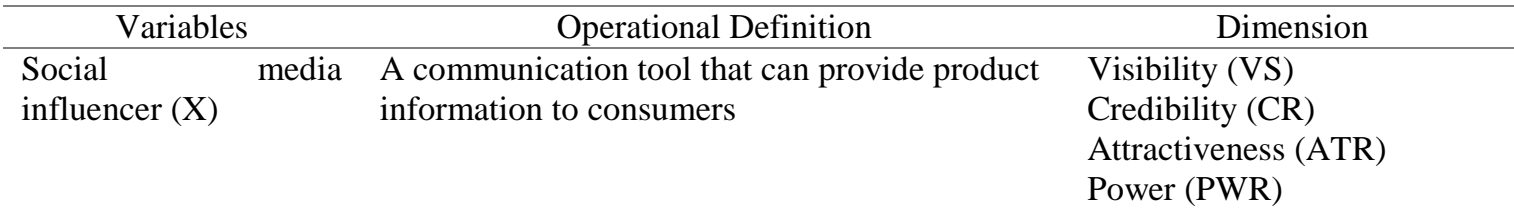

Brand Image (Z1) Consumer perceptions of brands are reflected through brand associations in consumer memory 


\begin{tabular}{lll}
\hline \multicolumn{1}{c}{ Variables } & \multicolumn{1}{c}{ Operational Definition } & \multicolumn{1}{c}{ Dimension } \\
\hline Self-Concept (Z2) & \multicolumn{1}{c}{$\begin{array}{l}\text { Character or personality of a person who shapes } \\
\text { perceptions of oneself so that it influences their } \\
\text { consumption behavior }\end{array}$} & $\begin{array}{l}\text { Conceptual (CEP) } \\
\text { Attitudinal (ATD) }\end{array}$ \\
Purchase Intention (Y) & $\begin{array}{l}\text { Consumer statement to oneself which reflects } \\
\text { the plan to purchase a number of products with } \\
\text { a certain brand }\end{array}$ & \\
\hline
\end{tabular}

\section{Validity Test}

The validity test measured the accuracy between the research data and the data occurred as the actual objects of the research. This stage was carried out using Statistical Package Social Science (SPSS) from the Windows version. The measuring instrument was the questionnaires, which would be valid if the questionnaires would interpret something that was measured. The questionnaire can be said to be valid if the question in the questionnaire is able to reveal something that will be measured by a a questionnaire. Validity test is done by correlating item scores with total scores. Spearman rank correlation if the data obtained is ordinal, whereas if the data obtained by interval we can use product moment correlation. From the results, it can be seen also the validity of each question item representing the research indicators.

Determaining the validity of an instrument is measured by comparing the $r$ statistic with r-table. The determination is presented as follow:

- $r$-statistic $>r$-table or sig value $r<0.05$ : valid

- $r$-statistic $<r$-table or sig value $r>0.005$ : invalid

If there are invalid items, then that invalid items should be discarded and the analysis process is repeated for only valid items. From that statement it can be concluded that if there is an invalid item, it should be retest with valid item.

\section{Reliability Test}

Reliability is a test that shows if a measuring instrument used in the study has reliability as a measuring instrument, including measuring the consistency of measuring result from time to time or can be said that reliability is a test that show how consistent the measurement results are when measured multiple times with the same measuring instrument. A data was declared as 'reliable' if the same data was generated in the same object and produced the same data of the research at different times. Meanwhile, the questionnaires could be considered reliable if the respondents answered the questionnaire consistently.

The reliability test would be conducted using SPSS for Windows. Research require data that is truly valid and reliable. In the framework of this urgency, the questionnaire was first tested into a sample of research trial before being used as a primary research data. The trial was conducted to obtain evidence of the extent to which the accuracy of measuring instrument in carrying out their measuring function. Question are said to be reliable if an answer to the question was consistent or stable over time. Measurement of reliability was done by one shot or just one measured using the SPSS program on scale analysis. Where the reliability was measured by Cronbach Alpha statistical tes, with a limitation of a variable said to be reliable if the value of Cronbach Alpha $>60$. 


\section{SEM Analysis}

The SEM (Structural Equation Model) was a powerful statistical technique that determined the measurement and structural models, as it was considered as the second generation of multivariate analysis. There were two types of SEM, the SEM-based covariance or better known as covariance-based structural equation modeling (CBSEM) and the partial least square path modeling (PLS-SEM). The CB-SEM was basically a parameter-oriented, with an approach based on the covariance-based relationship between the latent variables and reflective indicators. Meanwhile, the PLS was more oriented to predictions with a variance-based approach, concerning the relationship between latent variables and the reflective and formative indicators. PLS was also known as a soft-modeling analysis method because it did not add the assumption of the regression of the ordinary least square (OLS). The PLS could also be used to explain the possible relationship between latent variables or predictions, as well as confirming the theory.

Data that used in PLS-SEM does not have to meet the requirement for the assumption of normality, thus PLS-SEM give concession to data that are not normally distributed. PLS-SEM consist of three components, namely structural model, measurement model and weighting scheme. This third part is a special feature of PLSSEM and does not exist in covariant-based SEM. PLS-SEM only allows the relationship model between recursive variable only. This is the same as the path analysis model is not the same as covariant based SEM that allows the occurrence of non-recursive relationship. In the structural model, which is also called th einner model, all latent variables are connected to one another based on the theory of substance. Laten variables are divided into two, namely exogenous and endogenous. Exogenous latent variables are cause or variables without being proceded by other variables with arrow leading to other varables. Meanwhile, the measurement model, also known as the outer model, connects all manifest variables or indicators with their latent variables. In the SEM-PLS framework, one manifest varaible can only be connected with one latent variable. All manifest variable that are associated with one latent variable are referred to as a block. Thus each latent variable has a manifest variable block. A block must contain at least one indicator.

\section{Findings}

\section{Respondent Characteristic}

There were 219 respondents, with the demographic aspect used to explain the characteristics of respondents, including age, education level, types of work, and total income per month. Based on Table 2, the respondents of the research were mostly at the age between 20 to 30 years old, with the percentage of 74.9 percent. For the education level, the respondents were dominantly bachelor degree graduates with the percentage of 49.8 percent. The types of work of the most respondents were high school / college student with the percentage of 50.7 percent. Lastly, the total income of respondents per month was dominantly under Rp. 2,000,000 per month, with the percentage of 50.7 percent. 
Table 2 Respondents' characteristics

\begin{tabular}{|c|c|c|c|}
\hline Category & Profile & Total (n) & Percentage $(\%)$ \\
\hline \multirow{3}{*}{ Age } & $<20$ & 46 & 21 \\
\hline & $20-30$ & 164 & 74.9 \\
\hline & $31-50$ & 9 & 4.1 \\
\hline \multirow{4}{*}{ Education } & Senior High School & 87 & 39.7 \\
\hline & Diploma & 13 & 5.9 \\
\hline & Bachelor & 109 & 49.8 \\
\hline & Master & 10 & 4.6 \\
\hline \multirow{9}{*}{ Job } & Student & 111 & 50.7 \\
\hline & Employee & 58 & 26.5 \\
\hline & Civil Servant & 14 & 6.4 \\
\hline & Entrepreneur & 6 & 2.7 \\
\hline & Doctor & 2 & 0.9 \\
\hline & Housewife & 14 & 6.4 \\
\hline & Teacher & 4 & 1.8 \\
\hline & BUMN & 2 & 0.9 \\
\hline & Not Employee & 8 & 3.7 \\
\hline \multirow{6}{*}{ Salary per Month } & $<$ IDR2.000.000 & 111 & 50.7 \\
\hline & IDR $\quad 2.000 .000-$ IDR & 81 & 37 \\
\hline & 5.000 .000 & 25 & 11.4 \\
\hline & IDR $\quad 5.000 .001-$ IDR & 2 & 0.9 \\
\hline & 10.000 .000 & & \\
\hline & >IDR 10.000.000 & & \\
\hline
\end{tabular}

\section{Analysis of the Relationship between Social Media Influencer to Brand Image, Self-Concept and Purchase Intention}

The Structual Equation Modeling - Partial Least Square (SEM-PLS) analyzed the relationship between variables, using the external model assessment criteria, or the measurement model, and the assessment of the internal or structural model. The measurement model connected all of the manifested variables or indicators with their latent variables, by assessing the reliability and validity aspects. The structural model, which connected all the latent variables based on the existing theories, could be measured by analyzing the values of R2 and Q2. Furthermore, after the data had underwent the measurement requirements, a hypothesis would concluded using the bootstrapping method.

The social media influencers, as the endogenous variable of the research, had four dimensions: Visibility (VS), Credibility (CR), Attraction (ATR), and Power (PWR). The same also applied with the Purchase intention, as the exogenous variable, which also had four indicators: transactional interest (MB1), referential interest (MB2), preferential interest (MB3), and explorative interest (MB4). Furthermore, thee two intervening variables, brand image and self-concept, had three dimensions respectively. The brand image variable consisted of company image (CPU), product image (CPR) and service image (CPE), while the self-concept variable had perceptual (PER), conceptual (CEP), and attitudinal (ATD).

\section{Measurement Model}

The reliability test of the PLS SEM was interpreted with the value of Cronbach's Alpha, in addition to the composite reliability value. This value reflects the reliability of all indicators in the model. The minimum value wass 0.7 , with the ideal value around 
0.8 or 0.9 (Sarwono \& Narimawati, 2015). Each latent variable must be able to explain the variance of each indicator at least $50 \%$. Therefore, the absolute correlation between latent variable and the indicator must be more than 0.7 . Reflective indicators should be removed from th emeasurement model if the outside standard loadings value is below 0.4. As seen in Table 3, all the variables met the requirements of the reliability value, reflecting the reliability of each indicator in the model.

Table 3 Reliability test results

\begin{tabular}{lcccc}
\hline Variables & Composite Reliability & $\begin{array}{c}\text { Cronbach's } \\
\text { alpha }\end{array}$ & $\begin{array}{c}\text { Rule of } \\
\text { thumb }\end{array}$ & $\begin{array}{c}\text { Conclusio } \\
\mathrm{n}\end{array}$ \\
\hline Social Media Influencer & 0.904 & 0.884 & $>0.7$ & Reliable \\
Brand Image & 0.883 & 0.851 & $>0.7$ & Reliable \\
Self-Concept & 0.891 & 0.862 & $>0.7$ & Reliable \\
Purchase Intention & 0.905 & 0.860 & $>0.7$ & Reliable \\
\hline
\end{tabular}

The validity test of the PLS SEM could be explained through the values of the Average Variance Extracted (AVE) and loading factors, as well as the latent variables of the indicators. The indicators were considered as valid if the values of the loading factors were above 0.7 and could still be tolerated up to 0.5 . This value describes adequate validity which means that a latent variable is able to explain more than half of the variants of the indicator in the average. As seen in Table 4, all the indicators had the values of loading factors that met the requirements, which were above 0.5. These indicators could later be used for further testings.

Table 4 Loading factor values

\begin{tabular}{|c|c|c|c|c|c|}
\hline Indicators & Value & Conclusion & Indicators & Value & Conclusion \\
\hline VS1 & 0.727 & Valid & CPU3 & 0.710 & Valid \\
\hline VS2 & 0.872 & Valid & CPE1 & 0.809 & Valid \\
\hline VS3 & 0.804 & Valid & CPE2 & 0.863 & Valid \\
\hline CR1 & 0.856 & Valid & CPE3 & 0.790 & Valid \\
\hline CR2 & 0.874 & Valid & PER1 & 0.835 & Valid \\
\hline CR3 & 0.685 & Valid & PER2 & 0.690 & Valid \\
\hline ATR1 & 0.755 & Valid & PER3 & 0.822 & Valid \\
\hline ATR2 & 0.840 & Valid & CEP1 & 0.656 & Valid \\
\hline ATR3 & 0.815 & Valid & CEP2 & 0.895 & Valid \\
\hline PWR1 & 0.778 & Valid & CEP3 & 0.877 & Valid \\
\hline PWR2 & 0.716 & Valid & ATD1 & 0.846 & Valid \\
\hline PWR3 & 0.840 & Valid & ATD2 & 0.837 & Valid \\
\hline CPR1 & 0.771 & Valid & ATD3 & 0.741 & Valid \\
\hline CPR2 & 0.786 & Valid & MB1 & 0.867 & Valid \\
\hline CPR3 & 0.830 & Valid & MB2 & 0.876 & Valid \\
\hline CPU1 & 0.864 & Valid & MB3 & 0.808 & Valid \\
\hline CPU2 & 0.837 & Valid & MB4 & 0.805 & Valid \\
\hline
\end{tabular}

The AVE value of around 0.5 stated that one latent variable represented more than half of the variants of the average indicators (Sarwono and Narimawati, 2015). The AVE value, as seen in Table 5, showed that the value of the loading factors in all indicators has met the requirements above 0.5 , therefore that the indicator could be considered as 'valid'. 
Table 5 Result of Average Variance Extracted (AVE) values

\begin{tabular}{lccc}
\hline Variable & AVE & Rule of Thumb & Conclusion \\
\hline Attitudinal & 0.6551 & $>0.5$ & Valid \\
Attraction & 0.6465 & $>0.5$ & Valid \\
Service Image & 0.6749 & $>0.5$ & Valid \\
Company Image & 0.6339 & $>0.5$ & Valid \\
Product Image & 0.6508 & $>0.5$ & Valid \\
Conceptual & 0.6668 & $>0.5$ & Valid \\
Credibility & 0.6553 & $>0.5$ & Valid \\
Purchase Intention & 0.7053 & $>0.5$ & Valid \\
Perceptual & 0.6164 & $>0.5$ & Valid \\
Power & 0.6075 & $>0.5$ & Valid \\
Visibility & 0.6450 & $>0.5$ & Valid \\
\hline
\end{tabular}

\section{Structural Model}

The evaluation of the structural model could be conducted by analyzing the values of R2 and Q2. Based on data processing using SmartPLS 3.0, the R2 value was generated, as seen in Table 5. According to Sarwono and Narimawati (2015), the value of R2 measured the level of variation in each variable. As seen in Table, the latent variable of the brand image was around $36.3 \%$, indicating that the brand image variable could be explained by the influencer variable of $36.3 \%$ while the remaining $63.7 \%$ was explained by other factors. Furthermore, a consumer's self-concept could be explained by an influencer of $6.9 \%$. Meanwhile, the purchase intention variable had the value of R2 around $49.2 \%$, indicating that the variables of influencers, brand image and selfconcept could affect the purchase intention around $49.2 \%$. On the other hand, the rest was explained by other factors not included in the research model.

The acquisition of the R2 value calculated the value of Q2 or the relevance of predictions. The relevance value was used to analyze the relative influence of structural models on the measurement of the endogenous variable observation (Sarwono and Narimawati, 2015). The value of Q2 above 0 indicated that the model had a good predictive relevance, while the value of Q2 below 0 would lack a good predictive relevance. The calculation of the $\mathrm{Q} 2$ rate could be seen below.

$$
\begin{aligned}
\mathrm{Q}^{2} & =1-\left(1-\mathrm{R}_{1}^{2}\right)\left(1-\mathrm{R}_{2}^{2}\right) \ldots\left(1-\mathrm{R}_{\mathrm{p}}{ }^{2}\right) \\
\mathrm{Q}^{2} & =1-(1-0.363) \times(1-0.069) \times(1-0.492) \\
& =0.699
\end{aligned}
$$

The result of the Q2 acquisition was based on the calculation, which was 0.699. This indicated that the magnitude of the data diversity from the research could be explained by the structural model of $69 \%$, while the remaining $31 \%$ showed that other variables not included in the model could affect the purchase intention of local cosmetic consumers.

After fulfilling the measurement conditions, the next stage was the hypothesis testing, using the bootsrapping method on SmartPLS. According to Wong (2013), the bootstrapping method was performed by repeatedly taking new $\mathrm{N}$ samples from data of size $\mathrm{n}$, in this case by obtaining the sample points from the data one by one until $\mathrm{n}$ times. The hypothesis would be decided by comparing the values of $t$ count with $t$ table, with the level of confidence of $\alpha=0.05$ and a t table value of 1.96. The results of the $t$ test could be seen in Table 6 . 
Tabel 6 Statistical hypotheses test

\begin{tabular}{llccc}
\hline Hypothesis & Variables & $\begin{array}{c}\text { Original } \\
\text { Sample }\end{array}$ & T-value & Conclusion \\
\hline H1 & Social Media Influencer -> Purchase & 0.067 & 0.977 & Rejected \\
& Intention & & & \\
H2 & Social Media Influencer->Brand Image & 0.603 & 9.346 & Accepted \\
H3 & Social Media Influencer ->Self-Concept & 0.263 & 3.163 & Accepted \\
H4 & Brand Image -> Purchase Intention & 0.674 & 11.545 & Accepted \\
H5 & Self-Concept -> Purchase Intention & -0.0482 & 0.951 & Rejected \\
\hline
\end{tabular}

The result of the hypothesis test indicated that social media influencers did not had significant influences on the purchase intention ( $\mathrm{t}$-value $=0.977$ ), but had significant positive influences in the brand image ( $\mathrm{t}$-value $=9.346)$ and self-concept $(\mathrm{t}$ value $=3.163)$. Furthermore, the brand image had a significant positive influence towards the purchase intention $(\mathrm{t}$-value $=11,545)$, while the self-concept did not had a significant influence $(\mathrm{t}$-value $=0.951)$. The result stated that $\mathrm{H} 1$ and $\mathrm{H} 5$ were rejected, while $\mathrm{H} 2, \mathrm{H} 3$ and $\mathrm{H} 4$ were accepted.

In addition to conducting a hypothesis test, the SmartPLS calculation was also obtained through the calculation of indirect influences, in order to measure the strength of the connection between the mediator variable and other variables. Zhou et al. (2010) stated that the mediation was occured when a variable affected the relationship between the endogenous and exogenous variables. In this research, there were two variables used as the mediation or referred as the intervening variables, brand image and self-concept variables, that mediated the social media influencer variable with the purchase intention. The indirect effect value was also obtained through the bootstrapping test.

The magnitude rate of the indirect influence of social media influencers towards the purchase intention through a brand image was 0.407 , This rate was higher than the value of the direct influence of social media influencers towards the purchase intention (0.0677), stating that social media influencers could influence indirectly on the purchase intention through the brand image, in a positive and significant relationship. Meanwhile, the influence of social media influencers towrads the purchase intention through selfconcept had a negative relationship of -0.0127 , lower than the direct influence of social media influencers towards the purchase intention (0.0677), stating that social media influencers could not influence the purchase intention through the self-concept variable.

\section{Discussions}

The first result of the hypothesis test showed that there were no significant relationships between the influencers towards the purchase intention (H1 was rejected). The result was similar with a research by Johansen and Guldvik (2017), stating that there were no significant relationships between the influencers towards the purchase intention, but there would be an indirect influence through the attitudes toward behavioral variables. The influencers with firm opinions about their product reviews, along with equal negative and positive reviews could obtain positive results to consumers' attitudes towards influencers (Johansen \& Guldvik, 2017). Based on the indirect effect test, the influencers' social media accounts could influence the purcahse decision indirectly through the brand image variable, as analyzed by Hassan and Jamil (2014). Their research suggested that influencers could not attract consumers directly to 
commence purchases, but after watching good reviews from influencers, consumers would relate their perceptions with their own on the brand image, encouraging consumers to purchase the products.

The second result showed that there was a significant positive relationship between social media influencers and the brand image ( $\mathrm{H} 2$ was accepted). Godey et al. (2016) stated that the marketing practice through social media influencers had a significant influence on the brand equity of a product, considering that the brand image was an important aspect in the brand equity. Meanwhile, according to Hariyanti and Wirapraja (2018), social media influencers could increase the sales significantly and display a good brand image for consumers. In other words, they acted as intermediaries between companies and consumers in order to convey the product information to the consumers well. A research conducted by Barreda et al. (2015) showed that a word of mouth on social media could improve the company's brand image. In addition, the presence of influencer social media created a two-way communication that encouraged consumers to be indirectly connected with the company (Howard et al, 2014).

The third result showed that there was a significant positive relationship between social media influencers and the self-concept (H3 was accepted). This result was similar with the research conducted by Choi and Rifon (2012), stating that influencers had a significant relationship with consumers' self-concepts. Consumers would find similarities with social media influencers that could strengthen their own self-concepts. A strong self-concept of a consumer would influence the consumers wore clothes and used services and products (Khan, 2016).

The fourth result showed a significant positive relationship between brand image and the purchase intention ( $\mathrm{H} 4$ was accepted). According to a resaerch by Anggraeni and Asnawati (2017), a brand image could be implemented as an intervening variable between the endorsement and purchase intention because of the significant positive relationship between the brand image and consumers' purchase intention. Another research by Vien et al. (2017) stated that the brand image was one of the factors of brand attitude with a significant positive relationship to the purchase intention.

The fifth results furtherly indicated that there was no significant relationship between the self-concept and purchase intention (H5 was rejected). In accordance with Octaviani and Kartasasmita (2017), the self-concept did not significantly influence a consumption behavior. Another research by Gumulya and Widiastuti (2013) stated that the self-concept only represented the $0.6 \%$ of the consumers' behaviors. Moreover, Khan (2016) stated that consumers did not only match products with the self-concept in determining a purchase, but also matched products with the perception of brand image before having the purchase intention.

\section{Managerial Implication}

Demographically, the segmentation for local cosmetic products was mainly women around 20 to 30 years, with the total income of less than IDR 2.000 .000 per month and with higher education levels. The psycho-physical segmentation was the study environment that was interested in the cosmetics world and were active in social media. Nowadays, cosmetic users were increased and were not limited to career women, since high school and college students also started on using cosmetics a lot. This showed that the target consumers from teenage girls to adult women, who were active and had careers, were the right targets for the local cosmetics market. Cosmetics with 
premium quality, various color choices, elegant packagings, and affordable prices were the types of cosmetics that consumers tend to be interested, making the concept applied in product positioning.

\section{Conclusion and Recommendation}

\section{Conclusion}

Based on the results of the research, there were various conclusions to be formulated. One of which was social media influencers had a significant positive effect on the brand image of local cosmetic products and consumers' self-concept. Another conclusion was the brand image had a significant positive effect on the consumers' purchase intention, in contrast with the effect of the self-concept. In addition, the results of the following researches stated that the influencers did not significantly influence consumers on their purchase intention, but rather produced a significant positive effect indirectly through the brand image variable. Demographically, the segmentation of local cosmetic products was mainly women around 20 to 30 years, with the total income of less than IDR 2.000000 per month and with higher education levels, with the target consumers of teenage girs to adult women, who were active and had careers. Lastly, the suitable positioning was premium quality cosmetic products, with various color choices, elegant packagings, and affordable prices.

\section{Recommendation}

Based on the results of the research, there were several suggestions that could be implemented in further researches. Firstly, it was to recognize the name of one of social media influencers specifically in order to learn more about the influencers' characters, such as on improving the product's brand image. Since the brand image was a part of brand equity, the research model could be expanded by researching more about social media influencers with brand equity and purchase intention. Further researches were also recommended to add other compatible variables and produce better results.

\section{References}

Anggraeni, M., Asnawati, A. (2017). Pengaruh Celebrity Endorsement terhadap Purchase Intention dengan Brand Image sebagai Variabel Intervening (Studi Kasus Iklan Produk Perawatan Kecantikan Wardah). Prosiding Seminar Nasional Manajemen dan Ekonomi Bisnis, 1: 303-312.

Ateke, B.W. (2013). Marketing message effectiveness: The relevance of celebrity endorsement. The University Advanced Research Journal, 11, 14-22.

Barreda, A.A., Bilgihan A., Nusair K., Okumus F. (2015). Generating Brand Awareness n Online Social Networks. Computers in Human Behaviour, 50, 600-609. doi: 10.1016/j.chb.2015.03.023

Choi S.M., Rifon N.,J. (2012). It Is A Match: The Impact Of Congruence Between Celebrity Image And Consumer Ideal Self On Endorsement Effectiveness. Psychology and Marketing, 29(9), 639-650. doi: 10.1002/mar.20550.

Dân H.T., Nam L.,G. (2018). Impact of social media influencer marketing on consumer at Ho Chi Minh City. The International Journal of Social Sciences and Humanities Invention, 5(05), 4710-4714. doi: 10.18535/ijsshi/v5i5.10 
De Veirman M., Cauberghe V., Hudders L. (2017). Marketing through Instagram influencers: the impact of number of followers and product divergence on brand attitude. International Journal of Advertising, 36(5), 798-828. doi: 10.1080/02650487.2017.1348035

Godey B.N., Manthiou A., Pederzoli D., Rokka J., Aiello G., Donvito R., Singh R. (2016). Social Media Marketing Efforts of Luxury Brands: Influence on Brand Equity and Consumer Behaviour. Journal of Business Research, 69(12), 58335841. doi: 10.1016/j.jbusres.2016.04.181

Gumulya J., Widiastuti M. (2013). Pengaruh Konsep Diri Terhadap Perilaku Konsumtif Mahasiswa Universitas Esa Unggul. Jurnal Psikologi, 11(1),50-65.

Hassan S., Jamil R.A. (2014). Influencer of Celebrity Endorsement on Consumer Purchase Intention for Existing Product: A Comparative Study. Journal of Management Info, 4(1), 1-23.

Hariyanti N.T., Wirapraja A. (2018). Pengaruh Influencer Marketing sebagai Strategi Pemasaran Digital Era Modern (Sebuah Studi Literatur). Jurnal EKSEKUTIF, (15), 133-146.

Howard T., Mangold W.G., Johnston T. (2014). Managing your social campaign strategy using Facebook, Twitter, Instagram, YouTube \& Pinterest: An interview with Dana Howard, social media marketing manager. Business Horizons, 57, 657665.

Ilicic J., Webster C. (2015). Consumer Values Of Corporate And Celebrity Brand Associations. Qualitative Market Research: An International Journal, 18(2), 164187. doi: 10.1108/QMR-06-2013-0037

Johansen I.K., Guldvik C.S. (2017). Influencer Marketing and Purchase Intentions (thesis). Retrieved from https://brage.bibsys.no/xmlui/handle/11250/2453218

Khan M. (2006). Consumer Behaviour and Advertising Management. New Delhi, India: New Age International.

Labrecque L.I., Esche J., Mathwick C., Novak T.P., Hofacker C.F. (2013). Consumer Power: Evolution in the Digital Age. Journal of Interactive Marketing, 27, 257269. http://dx.doi.org/10.1016/j.intmar.2013.09.002.

Liu S., Jiang C., Lin Z., Ding Y., Duan R., Xu Z. (2015). Identifying effective influencers based on trust for electronic word-of-mouth marketing: A domainaware approach. Information Sciences, 306, 34-52. doi:10.1016/j.ins.2015.01.034

Loeper A., Steiner J., Stewart C. (2014). Influential Opinion Leaders. Economic Journal, 124 (581), 1147-1167. doi: 10.1111/ecoj.12100.

McCracken G. (1989). Who Is The Celebrity Endorser? Cultural Foundations Of The Endorsement Process. Journal of Consumer Research, 16, 310-321. doi: $10.1086 / 209217$.

Munukka J., Uusitalo O., Toivonen H. (2016). Credibility of a Peer Endorser and Advertising Effectiveness. Journal of Consumer Marketing, 33(3), 182-192. doi: 10.1108/JCM-11-2014-1221.

Opreana A., Vinerean S. (2015). A new development in online marketing: Introducing digital inbound marketing. Expert Journal of Marketing, 3(1), 29-34.

Park H., Cho H. (2012). Social Network Online Communities; Information Sources for Apparel Shopping. Journal of Consumer Marketing, 29(6), 400-411. doi: 10.1108/07363761211259214

Sarwono J., Narimawati S. (2015). Membuat Skripsi, Tesis dan Disertasi dengan Partial Least Square SEM (PLS-SEM). Yogyakarta, Indonesia: Andi. 
Sekhon T., Bickart B., Trudel R., Fournier S. (2016). Being a likable braggart: How consumers use brand mentions for self-presentation on social media. Consumer Psychology in a Social Media World, 23-39.

Solomon M.R. (2017). Consumer Behavior: Buying, Having, and Being 12th Edition. United States: Pearson Education.

Sumarwan U. (2015). Perilaku Konsumen: Teori dan Penerapannya dalam Pemasaran. Bogor, Indonesia: IPB Press.

Octaviani C., Kartasasmita S. (2017). Pengaruh Konsep Diri Terhadap Perilaku Konsumtif Pembelian Produk Kosmetik Pada Wanita Dewasa Awal. Jurnal Muara Ilmu Sosial, Humaniora, dan Seni, 1(2),126-133.

Tiago M., Veríssimo J. (2014). Digital Marketing and Social Media: Why Bother?. Business Horizons, 57(6), 703-708. doi: 10.1016/j.bushor.2014.07.002

Uzunoğlu E., Klip M. (2014). Brand Communication Through Digital Influencers. International Journal of Information Management, 34 (5), 592-602. doi: 10.1016/j.ijinfomgt.2014.04.007.

Vien C.V., Yun C.T., Fai P.L. (2017). The Effect of Celebrity Endorsement on Brand Attitude and Purchase Intention. Journal of Global Business and Social Entrepreneurship (GBSE), 1(4), 141-150.

Wang X., Yu C., Wei Y. (2012). Social Media Peer Communication and Impacts on Purchase Intentions: A Consumer Socialization Framework. Journal of Interactive Marketing, 26(4), 198-208. doi: 10.1016/j.intmar.2011.11.004.

Wong K.K. (2013). Partial Least Square Structural Equation Modeling (PLS-SEM) Techniques Using SmartPLS. Marketing Bulletin, 24(1), 1-32.

Yunita D., Rosa A. (2016). Pengaruh Mencari Variasi, Ketidakpuasan dan Ketidak Tersediaan Produk terhadap Perpindahan Merk. Jurnal Manajemen dna Bisnis Sriwijaya, 14(4), 539-558.

Zhou X., Lynch Jr. JG., Chen Q. (2010). Reconsidering Baron and Kenny : Myths and Truths about Mediation Analysis. Journal of Consumer Research, 37, 197-206. doi: $10.1086 / 651257$. 